\title{
The Bunch Moth of the Tirathaba Species As A Hidden Pest on The Peat Soil of Oil Palm Plantations: Implications of Biological Life Cycles, The DNA Barcoding Approach, and Infestation Pattern Detection
}

\author{
Salmah Yaakop ${ }^{1}$ and Shafariza Mohd Abdul Manaf ${ }^{2}$
}

\begin{abstract}
This study aims to investigate the life cycle of the bunch moth species, to analyze its DNA barcode and to identify the pattern of infestation on the bunch. The life cycle of the Tirathaba sp. from the larval to the adult stages was obtained through a rearing process in the laboratory. The status of the species has been confirmed as T. mundella based on DNA barcode data and helped by Neighbor-Joining and genetic distance analyses. Interestingly, the pattern of $T$. mundella infestation through monitoring and observation techniques that were described in this paper is a new finding. The findings of this study will bring a novel and fundamental approach to developing and planning the best and most efficient management strategies to control this hidden pest, the bunch moth.
\end{abstract}

Keywords-Bunch moth, Malaysia, Peat soil, Tirathaba.

\section{INTRODUCTION}

$\mathrm{T}$ HE bunch moth species, Tirathaba, is classified under the Pyralidae family, and there are only two recorded species from this family in Malaysia, namely $T$. mundella and $T$. rufivena [12]. Bunch moth infestations significantly reduce production yield and can infest a bunch per tree in $30 \%$ of all trees. Moreover, the percentage rises to $50 \%$ if no control programs are implemented to reduce the pest species population. In general, this species infests trees aged between three and five years [6]

Infestation happens at the larval stage of Tirathaba, starting with the male and female flower, the surface of the bunch, and the shoot of the frond. Due to the infestation, the fruit becomes rotten and consequently rots the whole bunch [2]. In Malaysia, with the exception of studies by [6] and Chan et al., little research has been done on this species, particularly in terms of its biology and genetics. Larval stages, genetic information, and infestation patterns are crucial data elements in managing and planning control strategies.

Salmah Yaakop ${ }^{1}$,Centre for Insect Systematics, School of Environmental and Natural Resource Sciences, Faculty of Science and Technology, Universiti Kebangsaan Malaysia, 43600 Bangi, Selangor, Malaysia.

Shafariza Mohd Abdul Manaf ${ }^{2}$,Centre for Insect Systematics, School of Environmental and Natural Resource Sciences, Faculty of Science and Technology, Universiti Kebangsaan Malaysia, 43600 Bangi, Selangor, Malaysia
Therefore, this study aims to obtain information about the life cycle of the Tirathaba by analyzing the DNA barcode for precise identification, and detecting and confirming the infestation patterns of the Tirathaba species, which may be confused with other insect pests in the plantation area.

\section{MATERIAL AND MethodS}

\section{A. Sample Collection}

The sampling of the Tirathaba was carried out in the Sungai Bebar Utara Plantation in Pahang, Malaysia from November 2013 to April 2014. A cross-sectional cut was made in the infested bunch so that the larval stage could be collected and brought to the laboratory to continue the rearing process.

\section{B. Infestation Observation}

The infestation pattern of the Tirathaba was detected, monitored, and photographed in the field, and this process was repeated six times for any available infestation using a Canon EOS DSLR 650D.

\section{Rearing Process}

Several samples of larval stages were collected randomly and reared in the laboratory. The larvae were kept in a transparent container measuring $24.5 \mathrm{~cm} \times 13.5 \mathrm{~cm} \times 13.0 \mathrm{~cm}$ and covered with a fine cloth mesh at a room temperature of 27 to $28^{\circ} \mathrm{C}$ and a relative humidity (RH) of 67 to $90 \%$ [11]. The development stages of the Tirathaba were obtained, recorded, and photographed with a Canon EOS DSLR 650D camera attached to a DV4 stereomicroscope (Carl Zeiss AG).

\section{DNA Barcoding Analysis}

\section{DNA Isolation, PCR, and Sequencing Analysis}

The DNA of a Tirathaba adult and larva from the rearing process was isolated using the general protocols of the DNeasy Blood \& Tissue Kit (Qiagen).Polymerase chain reaction (PCR) amplification was done using a set of universal primers designed by [5] in a $25 \mu \mathrm{L}$ reaction mixture consisting of a $2.5 \mu \mathrm{L} 10 \mathrm{X}$ PCR buffer; $1.3 \mu \mathrm{L} 50 \mathrm{mM} \mathrm{MgCl} 2 ; 0.5 \mu \mathrm{L} 10$ mMdNTPs; $0.5 \mu \mathrm{L}$ each of $10 \mathrm{pmol} / \mu \mathrm{L}$ primers; $0.5 \mathrm{U}$ Taq Polymerase (PROMEGA); and $4 \mu \mathrm{L}$ of DNA samples (6 $\mathrm{ng} / \mathrm{uL}$ ). A PCR profile was set for the initial denaturation step at $94^{\circ} \mathrm{C}$ for three minutes, followed by 40 cycles of $60 \mathrm{~s}$ at 
$94^{\circ} \mathrm{C}, 60 \mathrm{~s}$ at $47^{\circ} \mathrm{C}, 60 \mathrm{~s}$ at $72^{\circ} \mathrm{C}$, and a 10 -minute final extension at $72^{\circ} \mathrm{C}$. The product of the PCR was purified using the Geneaid Gel/PCR DNA Fragments Extraction Kit prior to sending to First Base Laboratories SdnBhd in Selangor, Malaysia for sequencing analysis.

\section{BLAST, Clustering, and Genetic Distance Analysis}

Sequences were searched by means of the basic local alignment search tool (BLAST) using the sequences available in the GenBank in order to identify highly similar sequences. Neighbor-joining analysis following a Kimura two-parameter model substitution with 1000 replications was then conducted and implemented using several Tirathaba sequences obtained from the Genbank with 100 replications for bootstrap analysis. The genetic distances between the Tirathaba species were also calculated.

\section{A. Life cycles}

\section{RESUltS AND DisCUSSION}

The Tirathaba was reared in the laboratory from the larval stage under controlled conditions to identify the life stages of the Tirathaba species. According to [4], it is easier to identify the Lepidoptera and beetle species in the adult stage than in the larval stage. In the rearing process, an oil palm bunch is used for food in the larval stages [10]-[11]. Besides the Tirathaba, nematodes and some Dipteran larvae inhabit the inner part of the bunches, especially rotten bunches. The Tirathaba can be differentiated due to the presence of prolegs and a wing pad in the larval stages [3]. The life cycle of the Tirathaba was then recorded (Figures 1a-e). In this study, five instar or larval stages of the Tirathaba species were identified, and it was found that the main difference between instars relates to size and body length.

\section{B. Species Identification}

Only two species of the Tirathaba have been recordedas being responsible for infestation in Malaysia and Indonesia, namely, the $T$. rufivena and the $T$. mundella [1]. According to [12], these species are easy to differentiate on the basis of the coloration on the front wing, which is greenish for the $T$. mundella and grayish for theT. rufivena. However, there is conflict between [1] and [8] regarding the characteristics of both species for identification purposes. Therefore, the molecular technique is the best to use if slight differences are detected between species in terms of their morphological characteristics [9]. In this study, DNA barcoding was carried out, followed by DNA isolation, PCR amplification using COI, and DNA purification. Sequencing was then performed to produce clustering analyses using Neighbor-Joining (NJ) criteria, supported by genetic distance analysis.

The (BLAST) analysis resulted in a similarity of only $89 \%$ with the $T$. rufivena sequence data available in the GenBank and revealed no sequence relating to $T$. mundella. Based on the result of a clustering analysis using NJ (Figure 2), the $T$. rufivenaJN270732 and the $T$. catharopa GU688824 were in the same clade and synonymized, while the Tirathaba larva (TL) and Tirathaba adult (TA) were separated and appeared not to belong to the same species. The genetic distance data also shows that the distance between the species above is 0.074-0.196 (Figure 3). Referring to the clustering and genetic distance results, the Tirathaba in this study belongs to the $T$. mundella. According to [7], no two species can survive and use similar sources in an ecosystem due to the competition factor.

\section{Pattern of Infestation}

Infestation by the $T$. mundella was detected using recordings and photographs in the field. The results of this paper are novel, since little research has been done to date on infestation pattern detection at the following stages of infestation: T. mundella larva infestation on the oil palm fruit mesocarp (Figure 8); the pattern of $T$. mundella leaving feces and a covering of silk on ripe and rotten bunches (Figures $7 \mathrm{a}-$ d); the pattern of infestation on the mesocarp 10 days after infestation (Figures 8a-c); the stunted growth of oil palm fruit caused by the T. mundella infestation (Figure 5); the hole on the mesocarp caused by $T$. mundella (Figures 6 a-b); the infestation on female flowers by $T$. mundella pupae (Figures $9 \mathrm{a}-\mathrm{b})$; and the infestation on non-ripening bunches of oil palm (figures 10a-b).

\section{CONCLUSION}

The species infesting the oil palm plantation in Sungai Bebar was confirmed as T. mundella using molecular data through genetic distance and clustering analyses. The life cycles of the species were also recorded and five instar stages determined. The most important new finding in this study relates to the pattern of infestation by the T. mundella. The results obtained from the study will contribute greatly to the management and planning of control programs for this pest species in the field.

\section{ACKNOWLEDGMENTS}

This research was funded by the FRGS/1/2014/SG03/UKM/02/1and GUP-2014-029 research grants.

\section{REFERENCES}

[1] F. Agus, P. Gunarso, B. H. Sahardjo, K. T. Joseph, A. Rashid, K. Hamzah, N. Harris, and M. van Noordwijk, "Reducing greenhouse gas emissions from land use changes for oil palm development". In 2011Presentation to plenary session, RSPO RT9,

[2] J. C. Alouw, B. Morallo-Rejesus, and V. R. Ocampo, "Biology of the coconut spike moth, Thirathaba fructivora (Meyr.) (Lepidoptera: Pyralidae),"Philipp.Entomol.vol.19, no. 1, pp 84-93, 2005.

[3] R. W. Bouchard, Jr, Diptera: Aquatic and semiaquatic true flies. Guideto Aquatic Macroinvertebrates of the UpperMidwest.St. Paul, MN: University of Minnesota, 2004.

[4] D. H. Choe, Pantrypest: Integrated pest management in the home. Pest note. Agriculture and Natural Resources. University of Carlifornia, 2013.

[5] O. Folmer, M. Black, W. Hoeh, R. Lutz, and R. Vrijenhoek, "DNA primers for amplification of mitochondrial cytochrome c oxidase subunit I from diverse metazoan invertebrates". Mol. Mar. Biol. and Biotechnol.,vol. 3, pp 294-299, 1994.

[6] K. H.Lim, "Integratedpestmanagement of Tirathaba bunch moth on oil palm planted on peat", ThePlanter, Kuala Lumpur,vol. 88, no. 1031, pp 97-104, 2012. 
[7] R. W. Matthews, and J. R.Matthew, InsectBehaviour, Springer link: Springer e-book, 2009.

[8] G. S. Robinson, R. T. Kevin, and M. Shaffer, A fieldguide to the smaller moths of South East Asia, Malaysian Nature Society, 1994.

[9] K. Sasakawa, "A novel technique for identifying the instar of field collected insect larvae."PLOSOne, vol.8, no. 2, pp 1-6, 2013. http://dx.doi.org/10.1371/journal.pone.0057836

[10] S. Sasaerila, R. Gries, G. Gries, G. Khaskin, S. King, and S. Takacs, "Sex pheromone components of male Thirathaba mundella (Lepidoptera: Pyralidae),”Chemoecology, vol.13, pp 89-93, 2003

[11] Y. Sasaerila, G. Geries, andR. Hardi, "Sexual communication by Thirathaba mundella (Lepidoptera: Pyralidae)," Can.Entomol.vol.134, no. 2, pp 251-253,2002. http://dx.doi.org/10.4039/Ent134250-2

[12] A. S. Susanto, and T. A. Perdana Rozziansha,"Organisme Pengangu Tanaman Penggerek tandan kelapa sawit Tirathaba mundella Walker," Pusat Penelitian Kelapa Sawit, volH (0004), pp 1-4, 2011

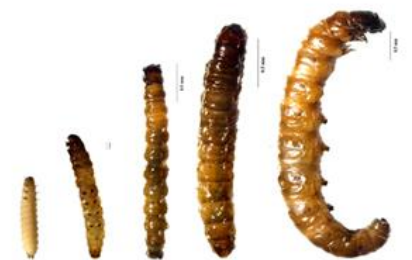

(a)



(c)

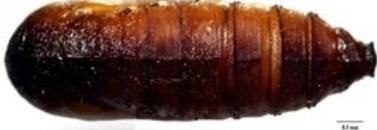

(b)



(d)

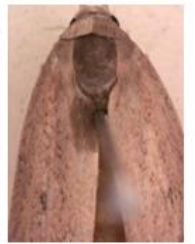

(e)
Fig. 1 (a)-(e) Life stages of the Tirathaba species: (a) five instar larvae (b) pupa (c) immature Tirathaba species (d) ventral view (e) dorsal view.

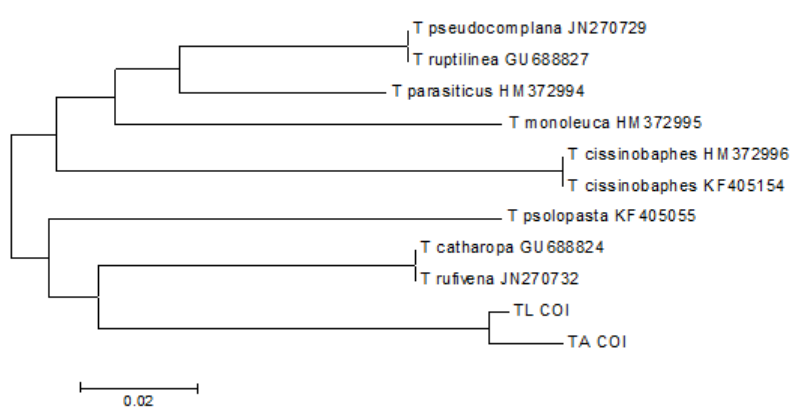

Fig. 2 Phylogeny of the Tirathaba species using a neighbor-joining (NJ) analysis

\begin{tabular}{|c|c|c|c|c|c|c|c|c|c|c|c|}
\hline & 1 & 2 & 3 & 4 & 5 & 6 & 7 & 8 & 9 & 10 & 11 \\
\hline \multicolumn{12}{|l|}{ 1. T pseudocomplana N270729 [ } \\
\hline 2. T dissinobaphes HM372996 & 0.151 & & & & & & & & & & \\
\hline 3. T monoleuca HM372995 & 0.123 & 0.156 & & & & & & & & & \\
\hline 4. T parasiticus HM372994 & 0.074 & 0.151 & 0.104 & & & & & & & & \\
\hline 5. Truptinea GU688827 & 0.000 & 0.151 & 0.123 & 0.074 & & & & & & & \\
\hline 6. T catharopa GU683824 & 0.127 & 0.165 & 0.151 & 0.127 & 0.127 & & & & & & \\
\hline 7. $T$ cosshobaphes $K=405154$ & 0.151 & 0.000 & 0.156 & 0.151 & 0.151 & 0.165 & & & & & \\
\hline 8. T psalopasta $K=405055$ & 0.137 & 0.173 & 0.172 & 0.155 & 0.137 & 0.147 & 0.173 & & & & \\
\hline 9. Trufivena JN270732 & 0.127 & 0.165 & 0.151 & 0.127 & 0.127 & 0.000 & 0.165 & 0.147 & & & \\
\hline 10. $\pi \mathrm{cot}$ & 0.139 & 0.187 & 0.169 & 0.135 & 0.139 & 0.124 & 0.187 & 0.143 & 0.124 & & \\
\hline 1. TA COI & 0.149 & 0.194 & 0.196 & 0.147 & 0.149 & 0.133 & 0.194 & 0.157 & 0.133 & 0.0 & \\
\hline
\end{tabular}

Fig. 3:Genetic distance between Tirathaba species



Fig. 4 Larva of the Tirathaba mundella infesting the surface of an oil palm mesocarp

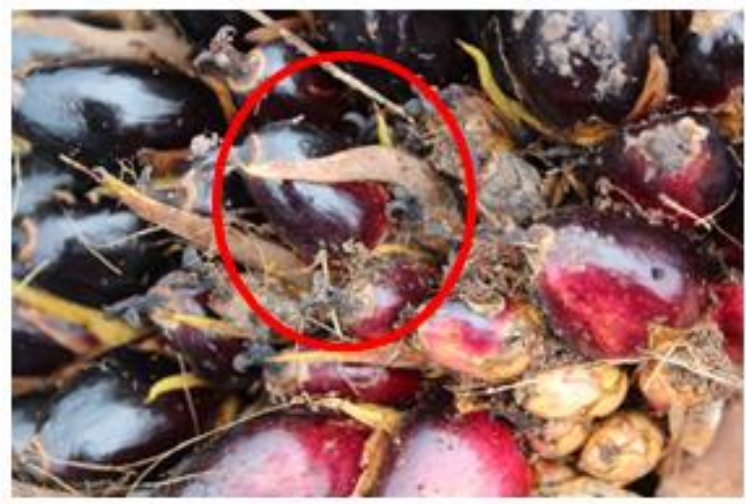

Fig. 5 Stunted growth of oil palm fruit caused by T. mundella infestation

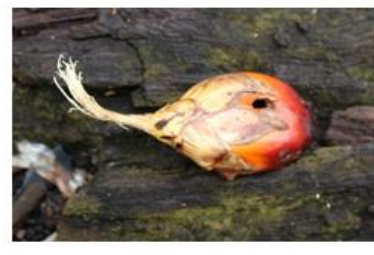



(b)
Fig. 6 (a)-(b) Hole made by the Tirathaba mundella on the mesocarp; (a) outer view (b) cross section



(a)

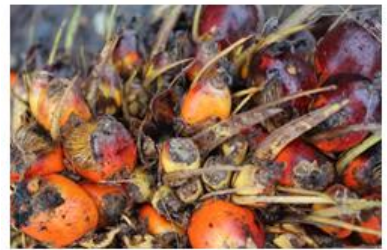

(c)

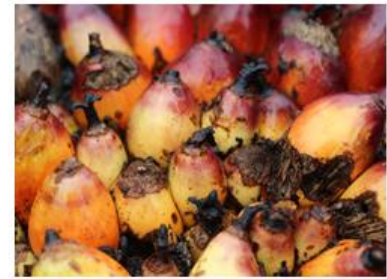

(b)

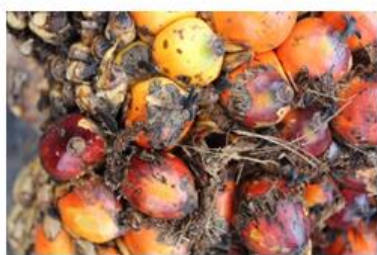

(d)
Fig. 7 (a)-(d) Pattern of T. mundella infestation on the surface of the ripening fruits of an oil palm mesocarp characterized by the feces and the silk covering it leaves on ripe or rotten bunches of the oil palm 


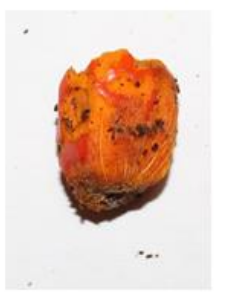

(a)

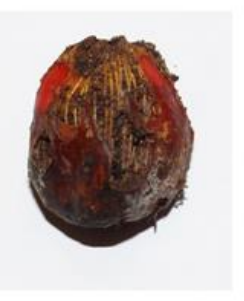

(b)

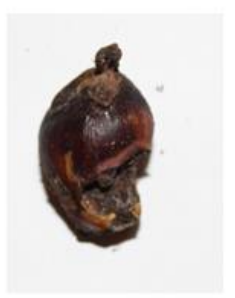

(c)

Fig. 8 (a)-(c) Pattern of infestation on the mesocarp of a fruit: (a) newly infested (b) five to six days after infestation (c) 10 days after infestation

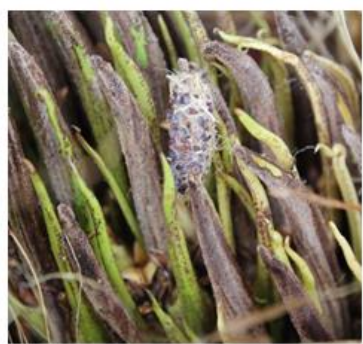

(a)



(b)

Fig. 9 (a)-(b) Pupae of Tirathaba mundella infesting the female flowers

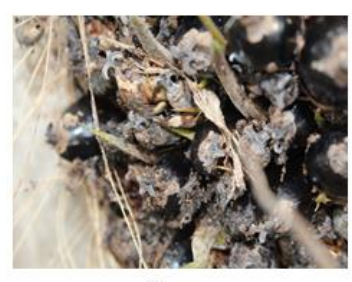

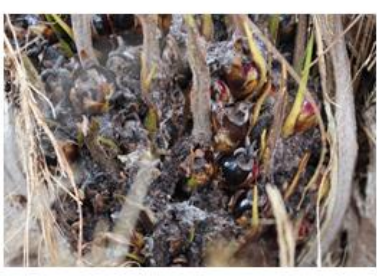

(b)

Fig. 10 (a)-(b): Infestation of Tirathaba mundella on a non-ripening oil palm bunch 